\title{
Kajian Dispersi Panas Akibat Air Limbah Rencana Pembangunan PLTU Kuala Tungkal - Provinsi Jambi
}

\author{
Study of Heat Dispersion due to Waste Water \\ from Development Plan of Kuala Tungkal Power Plant- \\ Province of Jambi
}

\author{
MARDI WIBOWO ${ }^{1)}$, VELLY ASVALIANTINA ${ }^{2)}$ \\ 1) Balai Teknologi Infrastruktur Pelabuhan dan Dinamika Pantai - \\ Badan Pengkajian dan Penerapan Teknologi JI. Grafika No. 2, SEKIP, Yogyakarta \\ 2) Kementerian Koordinator Maritim Republik Indonesia - Gedung I BPPT JI MH Thamrin no 8 Jakarta \\ mardi.wibowo@bppt.go.id
}

\begin{abstract}
Now to comply the electricity needs, government announced the construction of 10,000 MW power plant. One of its implementation by building Steam Power Plant (PLTU) with coal-fired power such as Kuala Tungkal in the District of Tanjab Barat, Province of Jambi. The main problem of power plant activities is the waste water temperatures much higher than the temperature of the surrounding waters. The rise of temperature will not only reduce the efficiency of the cooling system but also be harmful to aquatic life. To minimize the impact needs to be done advection/dispersion modeling of heat water prior to the construction of the power plant. With this modeling will be known distribution of heat waste from power plant in 3-dimensional, so that can be done since the beginning of efforts to reduce the negative impacts that arise. In addition this model can be used as a consideration in the determination of the location of the intake and outfall system cooling water. This study was conducted in several scenarios using software MIKE3. Based on modeling results is known that the intensity of the cooling water recirculation quite small $\left(<0.3{ }^{\circ} \mathrm{C}\right)$ predicted to occur when the tide gets worse when the river flow from upstream is reduced. The distribution of heat water with a temperature difference to the ambient water temperature $(\Delta T)>2{ }^{\circ} \mathrm{C}$, occurs only in a very limited area, which is a maximum of about $45 \mathrm{~m}$ to the east of the outfall location.
\end{abstract}

Keywords : thermal dispersion, steam powerplant, heat waste water, intake, outfall

\begin{abstract}
ABSTRAK
Saat ini untuk memenuhi kebutuhan energi listrik pemerintah mencanangkan program pembangunan pembangkit listrik $10.000 \mathrm{MW}$. Salah satu implementasinya dengan membangun Pembangkit Listrik Tenaga Uap (PLTU) berbahan bakar batubara seperti PLTU Kuala Tungkal di Kabupaten Tanjung Jabung Barat, Propinsi Jambi. Permasalahan utama kegiatan PLTU adalah suhu air buangan yang jauh lebih tinggi dari suhu perairan di sekitarnya. Kenaikan suhu ini selain akan mengurangi efisiensi sistem pendinginan juga dapat membahayakan kehidupan aquatik. Untuk meminimalkan dampak perlu dilakukan pemodelan adveksi/dispersi panas sebelum dilakukan pembangunan PLTU. Dengan pemodelan ini akan diketahui sebaran panas buangan PLTU secara 3-dimensi, sehingga sejak awal dapat dilakukan upaya-upaya untuk mengurangi dampak negatif yang muncul. Selain itu model ini dapat dipakai sebagai bahan pertimbangan dalam penentuan lokasi intake dan outfall sistem air pendingin. Studi ini dilakukan dalam beberapa skenario dengan menggunakan perangkat lunak MIKE 3 . Berdasarkan hasil pemodelan diketahui bahwa resirkulasi air pendingin dengan intensitas cukup kecil $\left(<0,3^{\circ} \mathrm{C}\right)$ diprediksi dapat terjadi pada saat air pasang menjadi lebih parah bila debit sungai dari hulu berkurang. Sebaran air bahang dengan perbedaan temperatur terhadap suhu air ambien $(\Delta T)>2{ }^{\circ} \mathrm{C}$, hanya terjadi pada daerah yang sangat terbatas, yaitu maksimum sekitar $45 \mathrm{~m}$ ke arah timur dari lokasi outfall.
\end{abstract}

Katakunci : dispersi panas, PLTU, air bahang, intake, outfall 


\section{PENDAHULUAN}

\subsection{Latar Belakang}

Seiring perkembangan pembangunan dan pertumbuhan ekonomi, kebutuhan energi listrik khususnya untuk industri juga semakin meningkat. Saat ini untuk memenuhi kebutuhan energi listrik tersebut pemerintah mencanangkan program pembangunan unit pembangkit 10.000 MW. Salah satu implementasinya dilakukan oleh PT. Perusahaan Listrik Negara (PLN) dengan membangun Pembangkit Listrik Tenaga Uap (PLTU) berbahan bakar batubara di beberapa daerah di Indonesia, termasuk salah satunya adalah pembangunan PLTU Kuala Tungkal di Kab. Tanjung Jabung Barat, Propinsi Jambi.

Berdasarkan data tahun 2009, pengguna energi listrik PLN menurut jumlah rumah tangga di Kabupaten Tanjung Jabung Barat baru mencapai 40,49\%. Sedangkan 26,30\% rumah tangga menggunakan listrik non ${ }^{\circ} \mathrm{PLN}$ sisanya yaitu sekitar 33,20\% menggunakan sumber energi lain (lampu petromaks, teplok dll) sebagai sumber penerangan ${ }^{(1)}$. Berdasarkan data tersebut dari 63.971 rumah tangga yang ada, yang menggunakan listrik PLN sebagai sumber penerangan hanya 25.902 rumah tangga atau sekitar 40,49 persen (2), Oleh karena itulah pemerintah Kab. Tanjung Jabung Barat bersama dengan PLN berusaha membangun pembangkit listrik baru salah satunya adalah PLTU di Kuala Tungkal.

Pembangunan PLTU selain membawa dampak positif juga akan menimbulkan dampak negatif terutama terhadap lingkungan. PLTU umumnya dibangun di dekat pantai atau sungai besar karena kemudahan untuk memperoleh air sebagai bahan utama sistem pendinginan mesin selain untuk air proses (air umpan boiler). Permasalahan utama kegiatan PLTU ini adalah suhu air buangan dari sistem pendingin yang jauh lebih tinggi dari suhu perairan di sekitarnya. Umumnya suhu air buangan tersebut dapat mencapai $40^{\circ} \mathrm{C}^{(3,4,5)}$. Sementara suhu perairan di sekitarnya hanya sekitar $30^{\circ} \mathrm{C}$. Pada umumnya penggunaan air pendingin pada beban penuh untuk setiap megawatt diperlukan sebanyak antara $45-55 \mathrm{~m}^{3} /$ detik $^{(4)}$. Proses fisik yang paling mendasar dalam transpor panas (heat transport) adalah ketika limbah panas masuk ke dalam badan air, hal ini menyebabkan suhu air meningkat sampai terjadi kehilangan keseimbangan panas di permukaan. Untuk keperluan komputasi, masuknya panas ke dalam badan air dikelompokkan menjadi dua zona, yakni badan air yang dekat dengan sumber buangan (near-field) dan jauh dari sumber buangan (far-field). Pada zona pertama, buangan bahan (heated discharge) diencerkan oleh adanya turbulen (discharge-induced turbulence).
Pada zona kedua yang berdekatan dengan zona pertama, distribusi bahang diatur oleh proses konveksi dengan adanya arus (convection by ambient currents), difusi karena adanya turbulen dan adanya pertukaran panas melalui permukaan laut ${ }^{(5)}$. Untuk memodelkan zona yang dekat dengan sumber akan lebih presisi jika dimodelkan menggunakan Computational Fluid Dynamics (CFD) 3D ${ }^{(6)}$. Pemodelan dengan MIKE telah memasukan perhitungan untuk zona dekat sumber dengan menggunakan modul "Coupled to the MIKE 3 Solution".

Secara kimia, kenaikan temperatur berpengaruh terhadap kecepatan reaksi dimana reaksi pada kondisi yang setimbang akan berubah sejalan dengan perubahan temperatur. Kecepatan reaksi akan naik sekitar dua kalinya untuk setiap kenaikan $10{ }^{\circ} \mathrm{C}^{(6)}$. Banyak reaksi yang mempengaruhi kualitas air yaitu reaksi biokimia di sekitar pusat aktivitas mikroba. Rasa dan bau terjadi pada air yang hangat karena terjadinya penurunan kelarutan terutama gas $\mathrm{H}_{2} \mathrm{~S}, \mathrm{SO}_{2}, \mathrm{CH}_{4}, \mathrm{SO}_{x}{ }^{(7)}$.

Pengaruh negatif lain adalah terhadap resirkulasi panas. Resirkulasi panas terjadi ketika ada kenaikan suhu di intake, kenaikan suhu ini akan mengurangi efisiensi sistem pendinginan, yang akhirnya mengurangi efisiensi PLTU.

PLTU Kuala Tungkal karena posisi intake dan outfall berada di muara $S$. Tungkal perlu memperhatikan dua baku mutu air yang ada. Baku mutu pertama adalah Peraturan Pemerintah No. 82 Tahun 2001 tentang Pengelolaan Kualitas Air dan Pengendalian Pencemaran Air ${ }^{(9)}$. Baku mutu kedua adalah Keputusan Menteri Lingkungan Hidup No. 51 Tahun 2004 tentang Baku Mutu Air Laut ${ }^{(10)}$ karena posisi inlet dan outfall meskipun berada di sungai tetapi sangat dekat dan dipengaruhi atau mempengaruhi kondisi perairan laut.

Pemodelan dispersi panas ini mensimulasikan proses perubahan atau sebaran panas akibat air buangan PLTU secara 3D, yang pada akhirnya dapat dimanfaatkan sebagai panduan untuk meminimalisasi dampak lingkungan yang mungkin akan timbul. Selain itu model ini diharapkan dapat dipakai sebagai bahan pertimbangan dalam penentuan lokasi intake dan outfall sistem air pendingin.

Penelitian ini dilakukan untuk mengetahui proses persebaran panas akibar air buangan PLTU dengan berbagai skenario sebagai bahan pertimbangan untuk menentukan lokasi intake dan outfall sistem air pendingin.

Studi ini dilakukan dalam beberapa skenario dengan menggunakan modul hidrodinamika dan modul adveksi/dispersi dalam perangkat lunak MIKE 3. Pemodelan sebaran panas dengan MIKE 21 (dua dimensi) pernah dilakukan untuk memodelkan sebaran panas air buangan PLTGU 
Cilegon dimana berdasarkan hasil verifikasi, model ini sangat baik dengan perbedaan suhu terhadap hasil pengukuran rata-rata kurang dari $0,5^{\circ} \mathrm{C}$ dan berpengaruh sampai jarak $\pm 2 \mathrm{~km}^{(3)}$. Hasil pemodelan lain menunjukkan bahwa jarak pengaruh air buangan ini menyebar sejauh 1.048 $\mathrm{km}$ dengan suhu $31^{\circ} \mathrm{C}-33^{\circ} \mathrm{C}^{(11)}$ dan ada yang mencapai jarak 1,2 km dengan suhu $33,9{ }^{\circ} \mathrm{C}(5)$. Selain dengan MIKE 21 pemodelan dispersi panas sering juga dilakukan dengan model PLIC$\operatorname{VOF}^{(8)}$, dengan model RMA $2^{(4)}$, Delft 3D$\mathrm{FLOW}^{(13)}$. Hasil verifikasi pemodelan hidrodinamika dan dispersi panas dengan MIKE 21 menunjukkan pola yang sama dengan hasil pengukuran di lapangan ${ }^{(3,14)}$ bahkan hasil penelitian pada buangan system pendingin fasilitas LNG di Teluk Kutch India menunjukkan koefisien korelasi antara hasil pemodelan dan pengukuran berkisar $86 \%-98 \%{ }^{(15)}$.

\section{BAHAN DAN METODE}

PLTU Kuala Tungkal dibangun di Kec. Tungkal Ilir, Kab. Tanjung Jabung Barat, Propinsi Jambi (lihat Gambar 1). Secara geografis terletak di sekitar 0,80 'LS dan 103,49 ${ }^{\circ} \mathrm{BT}$, terletak di sisi selatan muara Sungai Tungkal yang merupakan sungai terbesar di kabupaten ini. Lokasi tapak PLTU Kuala Tungkal ini terletak di sebelah utara Kota Jambi dengan jarak sekitar $125 \mathrm{Km}$ dan dapat ditempuh dalam waktu sekitar 2-3 jam melaui jalan darat.

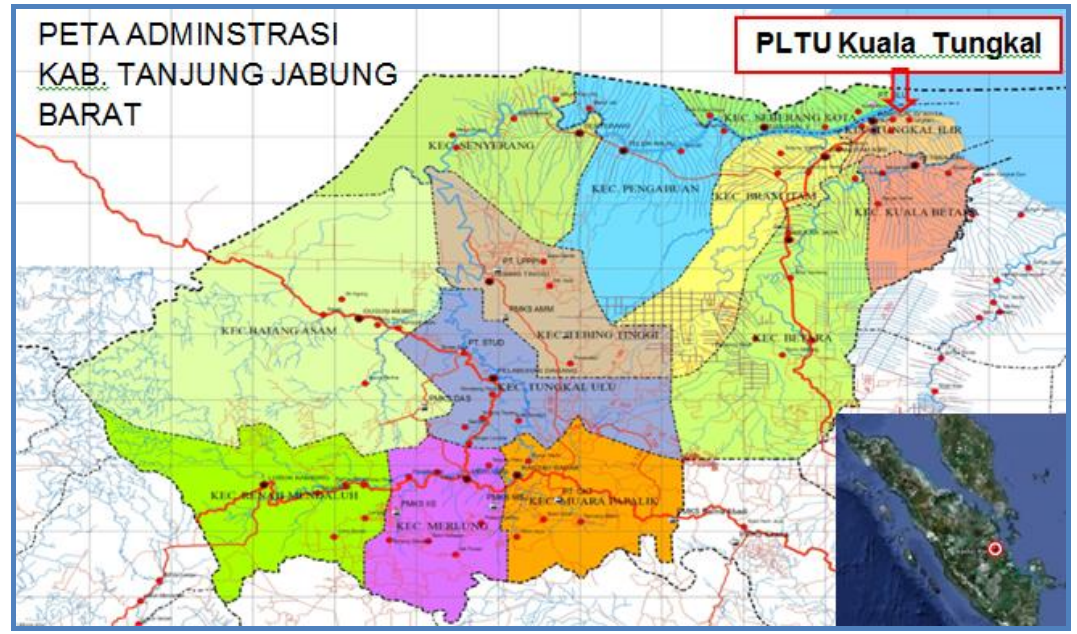

Gambar 1. Peta lokasi PLTU Kuala Tungkal

\subsection{Tahapan Pelaksanaan}

Lingkup dalam kajian ini adalah sebagai berikut :

a. Pengumpulan data sekunder (baik terkait data teknis hidro-oseanografi, data iklim, data hidrologi, data desain PLTU maupun data dan kajian yang sudah ada lainnya).

b. Survei lapangan untuk melakukan pengukuran batimetri, pengukuran arus dan pasang surut di beberapa lokasi sebagai dasar untuk validasi data dan verifikasi model.

c. Pemodelan hidrodinamika, untuk mengetahui pola tinggi permukaan perairan, arah dan kecepatan arus di sekitar lokasi PLTU.

d. Pemodelan adveksi dan dispersi panas, untuk mengetahui pola sebaran panas akibat air buangan PLTU di perairan sekitarnya. e. Dalam tiap pemodelan baik hidrodinamika maupun adveksi dan dispersi panas dilakukan tahapan sebagai berikut :

$\checkmark$ Menyusun skenario

$\checkmark$ Mendefinisikan domain model (area dan waktu)

$\checkmark$ Persiapan dan input data

$\checkmark$ Setup model

$\checkmark$ Kalibrasi dan verifikasi model

$\checkmark$ Pacu model

$\checkmark$ Analisis hasil model

$\checkmark$ Post-processing hasil pemodelan (animasi, peta dan pelaporan).

Pengamatan pasang surut dilakukan sejak tanggal 27 Agustus 2013 sampai dengan 27 September 2013 agar satu periode pasang surut terpenuhi. Palem ukur ditempatkan di dermaga penampungan udang ketak, di depan lokasi 
PLTU di lokasi yang diperkirakan air tidak sampai surut.

Pengukuran arus dilakukan dengan dua cara yaitu Metode Euleurian (metode ini merepresentasikan arah dan kecepatan arus sebagai fungsi dari waktu pada suatu titik lokasi dan Metode Lagrangian (dengan cara melabuhkan pelampung di permukaan air selama durasi waktu tertentu).

Dalam survei ini, pengukuran temperatur dan salinitas dilakukan menggunakan alat CTD (Conductivity, Temperature and Depth) model Minos $X$ yang diproduksi oleh AML Oceanography. CTD diturunkan dengan tali di tempat tertentu yang mewakili pada waktu yang sama dengan diturunkannya pelampung pengukur arus.

Peninjauan lapangan di sekitar rencana lokasi PLTU dan sekitarnya, kondisi inlet dan outlet, sungai dan struktur bangunan lainnya.

Untuk kajian model dispersi panas ini, digunakan MIKE 3 FM modul HD (hidrodinamika) yang merupakan modul dasar, serta $A D$ (adveksi dan difusi). Modul HD digunakan untuk memodelkan sirkulasi air dalam suatu perairan, sedangkan modul $A D$ digunakan untuk memodelkan pergerakan massa air (salinitas dan termperatur) serta konsentrasinya ${ }^{(10)}$. FM berarti "flexible mesh" yang memungkinkan kita untuk memodelkan bentuk morfologi yang tidak beraturan dengan lebih akurat.

\subsection{Data dan Input Model}

Adapun data yang diperlukan untuk melakukan pemodelan numerik hidrodinamika dan dispersi panas adalah sebagai berikut ${ }^{(10)}$ :

a. Batasan daerah model (model domain) dan waktu

b. Faktor kalibrasi, meliputi : gesekan dasar, gesekan angin dan koefisien dispersi

c. Kondisi awal yang meliputi elevasi permukaan air dan temperatur/salinitas

d. Syarat batas, yang meliputi syarat batas tertutup (pantai atau struktur)

e. Batas terbuka berupa elevasi muka air ataupun debit sungai.

f. Gaya penggerak lainnya seperti pasang surut, angin, gelombang dan sink/source.

\section{Batimetri}

Batimetri atau kedalaman perairan di lokasi studi umumnya relatif dangkal, berkisar antara 0 $7 \mathrm{~m} \mathrm{LWS}^{(16)}$. Pada kajian ini data batimetri yang dipakai bersumber dari peta Dinas Hidrooseanografi (DISHIDROS) TNI-AL yang telah didigitasi untuk mendapatkan data kedalaman serta garis batas daratnya, ditambah dengan data hasil pengukuran yang dilakukan serta data garis pantai dari google earth ${ }^{(16)}$.

\section{Pasang surut}

Berdasarkan hasil pengamatan pasang surut dan perhitungan konstanta pasut, tipe pasang surut di perairan Kuala Tungkal adalah campuran condong harian ganda, yaitu mengalami dua kali pasang dan dua kali surut selama 24 jam $^{(16)}$. Data pasang surut digunakan untuk syarat batas model, kalibrasi serta verifikasi hasil model. Grafik data pasang surut hasil pengamatan, hasil perhitungan serta residualnya terlihat pada gambar 2 berikut ini.

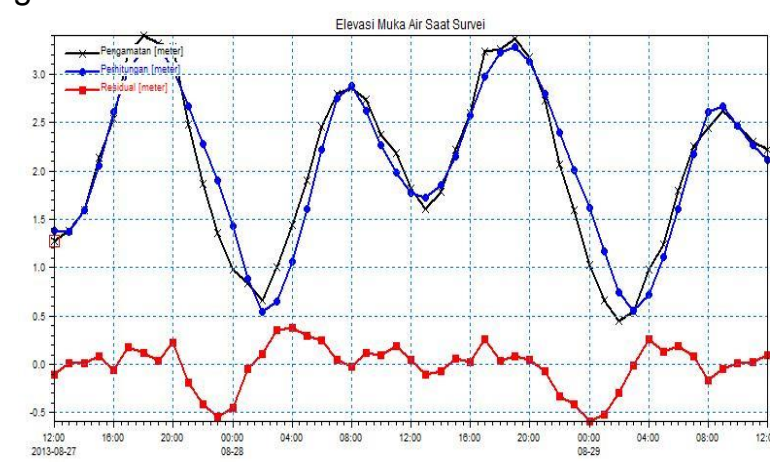

Gambar 2. Grafik elevasi permukaan air hasil pengamatan (hitam), perhitungan (biru) dan selisih keduanya (merah) selama survei tanggal $27 \quad-29$ Agustus $2013^{(16)}$.

\section{Arah dan Kecepatan Arus}

Kondisi arus di muara Sungai Tungkal didominasi oleh arus pasut dan aliran/debit sungai dari hulu. Dominasi debit dari hulu akan signifikan khususnya pada musim penghujan. Kecepatan arus maksimum di saat menuju pasang sebesar $0,83 \mathrm{~m} /$ detik. Sedangkan saat menuju surut, arus maksimum tercatat sebesar $0,67 \mathrm{~m} /$ detik. Arus dominan mengalir ke arah timur pada saat surut dan kearah barat-daya saat terjadi pasang ${ }^{(16)}$. 


\section{Temperatur dan Salinitas Perairan}

Berdasarkan pengukuran lapangan, terlihat stratifikasi salinitas dan temperatur terhadap kedalaman di perairan Sungai Tungkal. Sepanjang ruas sungai, salinitas cenderung payau ( $>16$ PSU) yang menunjukkan pengaruh pasang surut laut sangat kuat hingga jarak $6 \mathrm{~km}$ dari mulut estuari. Salinitas yang terukur antara 16-25 PSU, dan temperatur antara $28^{\circ} \mathrm{C}-$ $31^{\circ} \mathrm{C}^{(16)}$.

\section{Kondisi Meteorologi dan Klimatologi}

Sebagaimana wilayah timur pulau Sumatera lainnya, musim hujan di Provinsi Jambi terjadi pada bulan Oktober sampai dengan April dan musim kemarau dari bulan Mei sampai September.

Tabel 1 berikut adalah data meteorologi dan klimatologi yang digunakan dalam kajian ini :

Tabel 1. Data meteorologi dan klimatologi

\begin{tabular}{|c|c|c|c|}
\hline Kelembaban udara: & Temperatur: & Angin: & Penyinaran Matahari : \\
\hline $\begin{array}{l}\text { Max }: 90,0 \% \\
\text { Min }: 75,0 \% \\
\text { Rata-rata }: 82,5 \%\end{array}$ & $\begin{array}{ll}\text { Max } & : 32^{\circ} \mathrm{C} \\
\text { Min } & : 27^{\circ} \mathrm{C} \\
\text { Rata-rata } & : 29,5^{\circ} \mathrm{C}\end{array}$ & $\begin{array}{l}\text { Angin dominan dari } \\
\text { Tenggara, Utara dan } \\
\text { Selatan. Kecepatan } \\
\text { maksimum adalah } 9 \text { knot } \\
\text { (4,6 m/detik), dengan arah } \\
\text { dominan dari Tenggara. }\end{array}$ & $\begin{array}{l}\text { Rata-rata penyinaran matahari } \\
\text { berkisar antara } 3 \text { jam/hari } \\
\text { (bulan November) hingga } 6,7 \\
\text { jam/hari (bulan Juli/Agustus) }\end{array}$ \\
\hline
\end{tabular}

Sumber :Stasiun Meteorologi Sultan Thaha Jambi (Tahun 2011)(17)

\section{Data Intake dan Outfall}

Lokasi intake dan outfall air pendingin PLTU terlihat pada gambar berikut ini. Uji pemodelan numerik dilakukan terhadap dua alternatif lokasi intake dan outfall dari PLTU Kuala Tungkal, dengan rincian sebagai berikut (koordinat dalam sistem UTM 48, WGS 84) $)^{(17):}$

\section{Alternatif 1:}

Intake:

Outfall:

$\mathrm{X}=331764.42236$,

$\mathrm{X}=332040.31824$,

$Y=9911270.80260$,

$Y=9911210.96090$,

$Z=-3.5$

$\mathrm{Z}=+1.0 \mathrm{MSL}$

\section{Alternatif 2:}

Intake:

Outfall:

$\mathrm{X}=331764.42236$,

$Y=9911270.80260$,

$\mathrm{X}=332075.9000$

$Y=9911214.35000$,

$Z=-3.5$

$\mathrm{Z}=+1.0 \mathrm{MSL}$

Suhu air panas buangan yang keluar dari outlet condensor maksimum $39^{\circ} \mathrm{C}$. Lokasi outlet condensor dan outfall di pantai dihubungkan oleh kanal terbuka ${ }^{(11)}$.

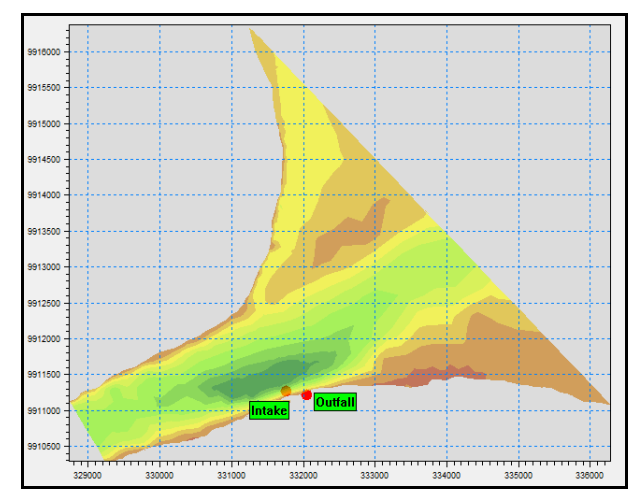

Gambar 3. Lokasi intake dan outfall pada domain model

\section{Skenario dan set-up model}

Studi ini dilakukan dalam beberapa skenario dengan menggunakan modul hidrodinamika dan modul adveksi dispersi dalam perangkat lunak MIKE 3. Simulasi dilakukan untuk dua skenario model dengan memperhatikan kondisi angin musim, yaitu: Musim Barat dan Musim Timur. Saat musim barat angin bertiup dari arah UtaraBarat Laut, sedangkan saat musim timur arah angin dominan dari tenggara. Dalam pemodelan ini angin diasumsikan konstan dalam ruang dan waktu yakni $4 \mathrm{~m} /$ detik dari arah Barat Laut $\left(350^{\circ}\right)$ untuk kondisi musim barat dan dari arah Tenggara $\left(135^{\circ}\right)$ pada musim timur.

Semua skenario simulasi dilakukan dengan input parameter lainnya sebagai berikut ${ }^{(17)}$ : 
- Debit aliran intake $\left(Q_{\text {in }}\right)=$ debit yang keluar dari outlet $\left(Q_{\text {out }}\right)=4 \times 1250 \mathrm{~m}^{3} / \mathrm{jam}(\mathrm{Q}=1,39$ $\mathrm{m}^{3} /$ detik)

- Suhu air bahang yang keluar dari outfall di perairan/pantai $\left(T_{s}\right)=33^{\circ} \mathrm{C}$

- Temperatur air laut (ambien), $T_{a}=29^{\circ} \mathrm{C}$

- Temperatur udara rata-rata $=29,5{ }^{\circ} \mathrm{C}$, temperatur udara maksimum $=32{ }^{\circ} \mathrm{C}$

- Kelembaban relatif, $\mathrm{RH}=90 \%$

- Debit sungai sebagi syarat batas hulu Qs = $300 \mathrm{~m}^{3} /$ detik (konstan).

Domain model (batimetri) kajian ini, terdiri atas 2.497 elemen perhitungan numerik (berbentuk segitiga), dengan jumlah node seluruhnya sebanyak 1.560 node. Elemenelemen mesh ukuran/luasnya dibuat bervariasi; dalam hal ini untuk perairan di sekitar lokasi PLTU, mesh dibuat rapat sehingga diperoleh informasi yang lebih detil dibandingkan daerah lainnya dalam domain model. Dalam kajian ini, kedalaman perairan dibuat menjadi 4 lapisan vertikal berjarak sama (uniform equidistant). Dalam hal ini lokasi intake berada di lapisan dekat dasar pada kedalaman -3,5 m MSL, sedangkan lokasi outfall adalah pada lapisan permukaan $\pm 1,0 \mathrm{~m} \mathrm{MSL}$.

\section{HASIL DAN PEMBAHASAN}

\subsection{Pemodelan Hidrodinamika}

a. Musim Timur

Berdasarkan data klimatologi daerah setempat, musim angin Timuran terjadi pada bulan Mei - September. Pada bulan-bulan tersebut curah hujan relatif kecil, khususnya pada puncak musim kemarau yang terjadi pada bulan Agustus, intensitas curah hujan $31 \mathrm{~mm}^{(1)}$. Pada skenario musim Timur ini, sirkulasi hidrodinamika digerakkan oleh pasang surut, debit sungai, dan angin yang bertiup secara konstan dalam ruang dan waktu dengan kecepatan angin $=4 \mathrm{~m} / \mathrm{s}$, dari arah Tenggara $\left(135^{\circ} \mathrm{N}\right)$.

b. Musim Barat

Musim angin barat terjadi pada bulan Oktober - April. Pada bulan-bulan tersebut curah hujan di lokasi studi cukup tinggi, dengan puncaknya terjadi sekitar bulan April dengan intensitas $346 \mathrm{~mm}$. Pada simulasi ini, sirkulasi hidrodinamika digerakkan oleh pasang surut, debit sungai, dan angin barat yang bertiup secara konstan dalam ruang dan waktu dengan kecepatan angin $=4 \mathrm{~m} / \mathrm{s}$, dari arah Utara - Barat Laut $\left(350^{\circ} \mathrm{N}\right)$.

Hasil pemodelan hidrodinamika memperlihatkan bahwa pola arus di perairan sekitar PLTU serta lokasi yang berada di dalam badan sungai polanya tidak berbeda signifikan untuk kedua skenario musim tersebut. Sedangkan di lokasi perairan lebih luar dari mulut sungai (berbatasan dengan Selat Berhala), pola arus terlihat mulai dipengaruhi oleh angin dominan yang bertiup.

Validasi model hidrodinamika dilakukan dengan membandingkan tinggi muka air hasil pengukuran dengan tinggi muka air hasil pemodelan. Elevasi muka air hasil model sangat mirip dengan hasil pengukuran.

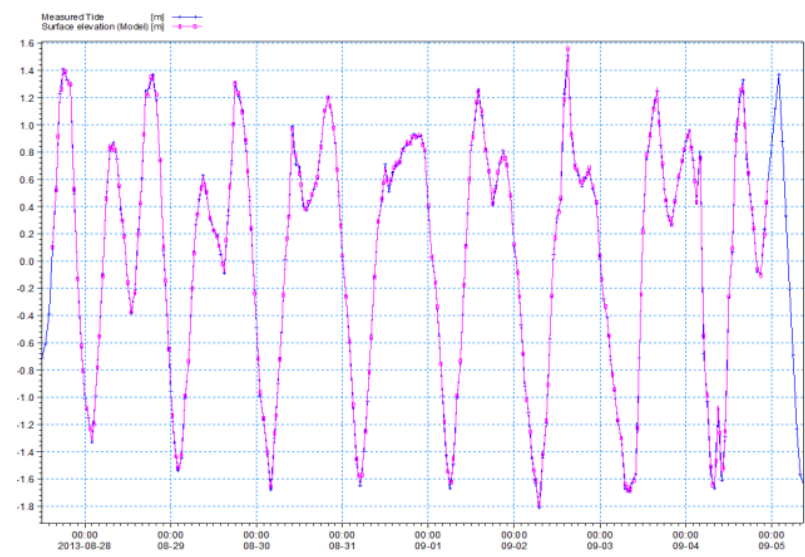

Gambar 4. Perbandingan evelasi muka air hasil pengukuran dengan hasil model

\subsection{Pemodelan Dispersi Thermal}

a. Uji Alternatif Lokasi Outfall

Uji model numerik dispersi panas dilakukan terhadap 2 (dua) alternatif lokasi outfall, Kedua alternatif lokasi outfall satu sama lain berjarak sekitar $175 \mathrm{~m}$. Pengujian dilakukan untuk mendapatkan lokasi outfall yang paling optimum sehingga kemungkinan terjadinya resirkulasi air pendingin dapat diminimalisir. Hasil pengujian berupa temperatur air di lokasi intake ditampilkan pada gambar 6 - 9 .

Grafik temperatur pada gambar 6 - 9 merupakan nilai temperatur air hasil ekstraksi dari simulasi dispersi panas di lokasi rencana intake, yaitu pada koordinat UTM-48 (331764.422, 9911270.802) di dasar perairan dengan kedalaman -3.5 MSL atau Layer 1 pada simulasi dengan MIKE 3. 
Grafik pada gambar berikut merupakan hasil simulasi dengan memperhitungkan faktor pasang surut perubahan temperatur air dan udara permukaan yang mencapai puncaknya pada tengah hari sekitar jam 12 siang, dan turun pada sore hingga malam hari dengan nilai terendah pada dini hari sekitar pukul 2 pagi.

Berdasarkan pemodelan tersebut secara umum penempatan lokasi outfall alternatif 1 dan 2 tidak memberikan perbedaan yang signifikan terhadap temperatur di lokasi intake. Pada gambar terlihat bahwa puncak- puncak kenaikan temperatur intake pada simulasi dengan outfall alternatif 2 sedikit lebih tinggi dibandingkan hasil simulasi dengan outfall alternatif 1 . Hal ini berkaitan erat dengan kondisi batimetri/kedalaman perairan di sekitar lokasi outfall. Dalam hal ini, kedalaman perairan di lokasi outfall alternatif 2 lebih dangkal dibandingkan kedalaman di sekitar outfall alternatif 1 . Perubahan temperatur maksimum ( $\Delta \mathrm{T}$ max) terjadi pada saat pasang-surut maksimum seperti terlihat pada gambar berikut dan nilainya disajikan pada Tabel 2 .

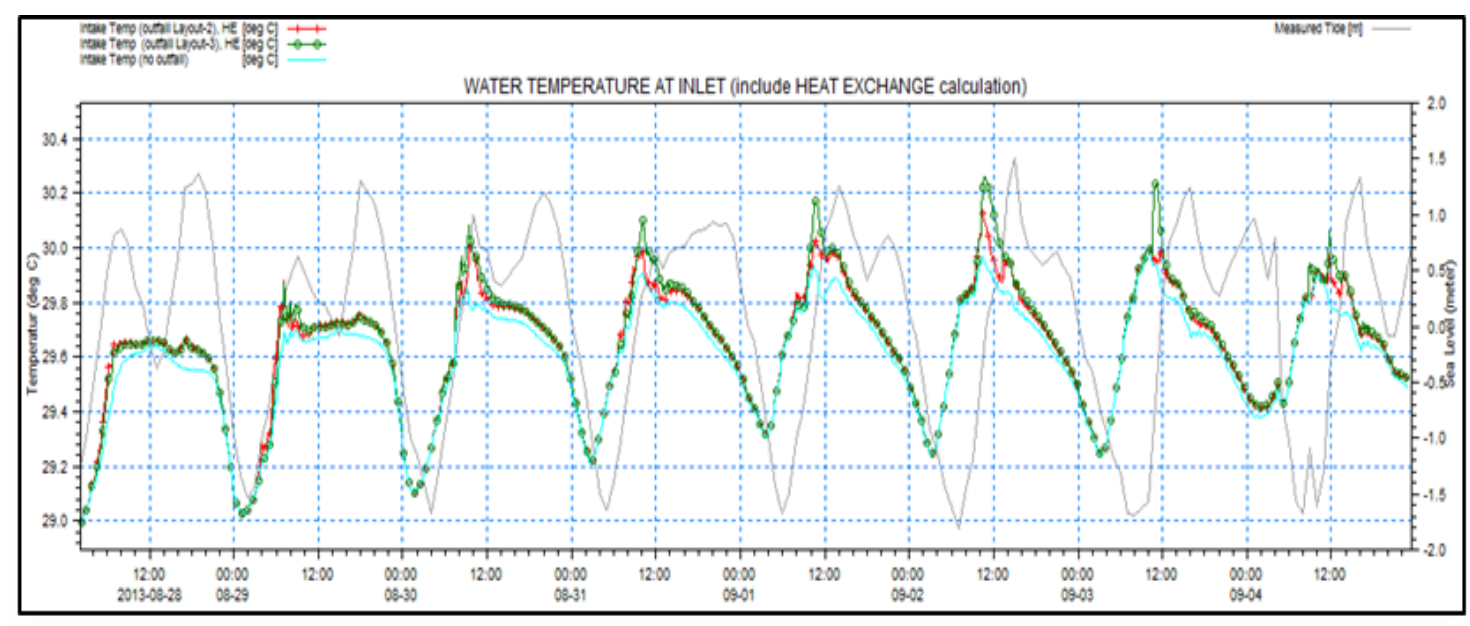

Gambar 5. Temperatur air di lokasi intake

Tabel 2. Selisih temperatur terhadap temperatur ambien ( $\delta \mathrm{t})$ maksimum di lokasi intake untuk berbagai skenario simulasi

\begin{tabular}{ccc}
\hline Posisi & $\begin{array}{c}\Delta \mathrm{T} \max \left({ }^{\circ} \mathrm{C}\right) \\
\text { Outfall } \\
\text { Exphange) }\end{array}$ & $\begin{array}{c}\Delta \mathrm{T} \max \left({ }^{\circ} \mathrm{C}\right) \\
(\text { Dengan Heat } \\
\text { Exchange) }\end{array}$ \\
\hline Alternatif 1 & 0.25 & 0.2 \\
\hline Alternatif 2 & 0.3 & 0.35 \\
\hline
\end{tabular}

\section{b. Pola Sebaran Air Bahang}

Hasil simulasi menunjukkan bahwa sebaran air bahang dengan perbedaan temperatur terhadap suhu air ambien $(\Delta \mathrm{T}) \quad 0.5^{\circ} \mathrm{C}-1^{\circ} \mathrm{C}$ mencapai jarak terjauh $300 \mathrm{~m}$ dari outfall ke arah hilir/timur-laut saat menuju surut, dan $300 \mathrm{~m}$ ke arah hulu/barat daya saat air menuju pasang.

Sebaran air bahang dengan $\Delta \mathrm{T}>2^{\circ} \mathrm{C}$, pada grafik hasil simulasi ditunjukkan dengan area berwarna merah. Area 'merah' terbesar terjadi pada kondisi pasut menuju surut, dengan jarak terjauh $30 \mathrm{~m}$ pada skenario musim timur, sedangkan pada musim barat mencapai $45 \mathrm{~m}$ ke arah timur outfall. Penyebaran kenaikan suhu hasil model ini tidak sejauh hasil-hasil penelitian yang terdahulu karena debit air buangan PLTU ini relatif kecil, selain itu juga karena pengaruh debit sungai yang sangat besar dan pasang surut dari arah laut. 


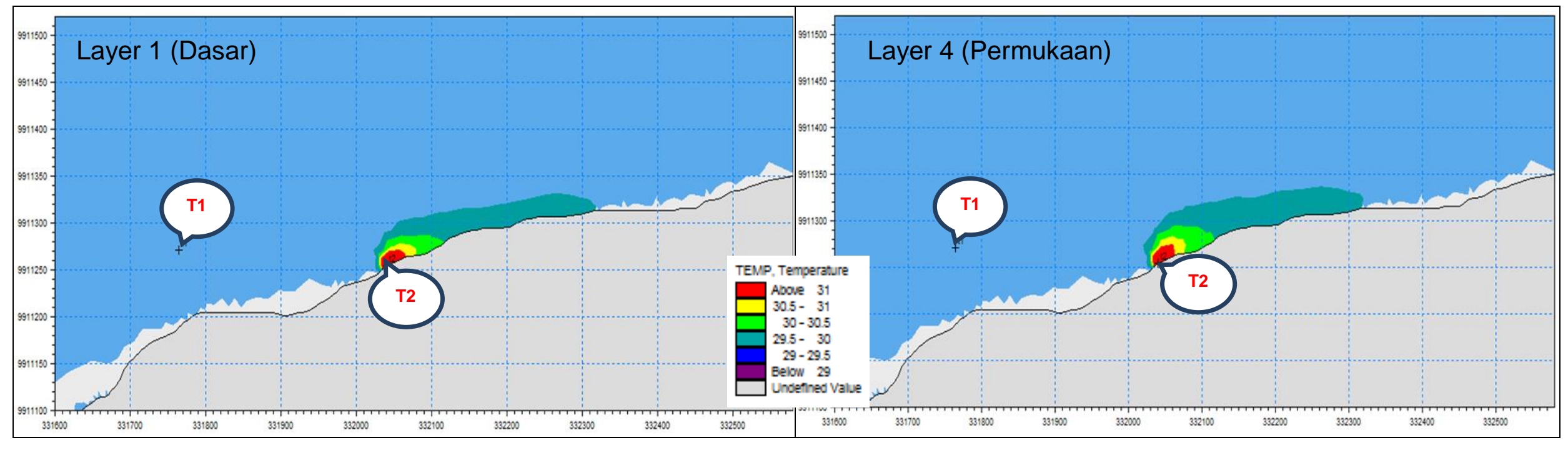

Gambar 6. Pola Dispersi panas skenario musim angin timur, kondisi menuju surut (Keterangan gambar: T1=Intake, T2=Outfall)

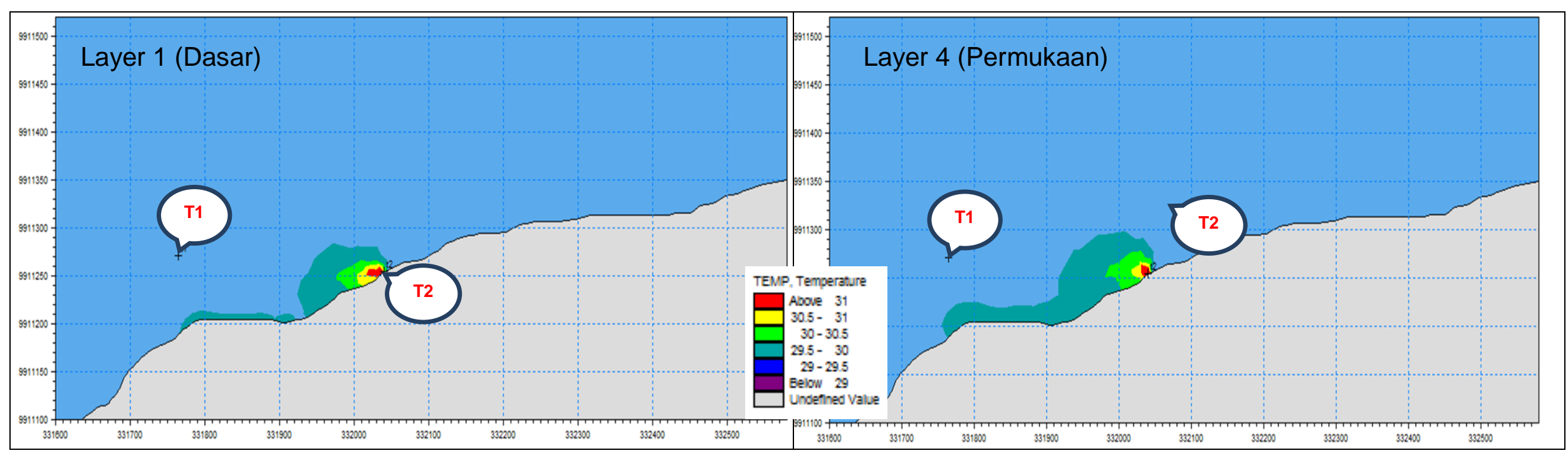

Gambar 71. Pola dispersi panas skenario musim angin timur, kondisi menuju pasang (Keterangan gambar: $\mathrm{T} 1=$ Intake, T2=Outfall) 


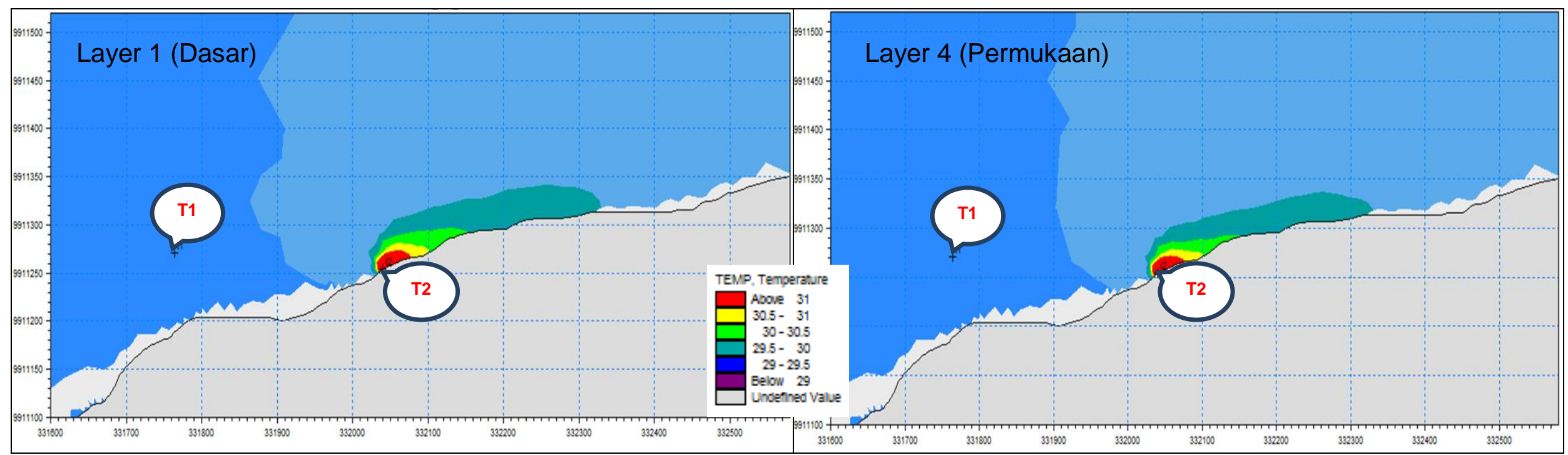

Gambar 8. Pola dispersi panas skenario musim angin barat, kondisi menuju surut

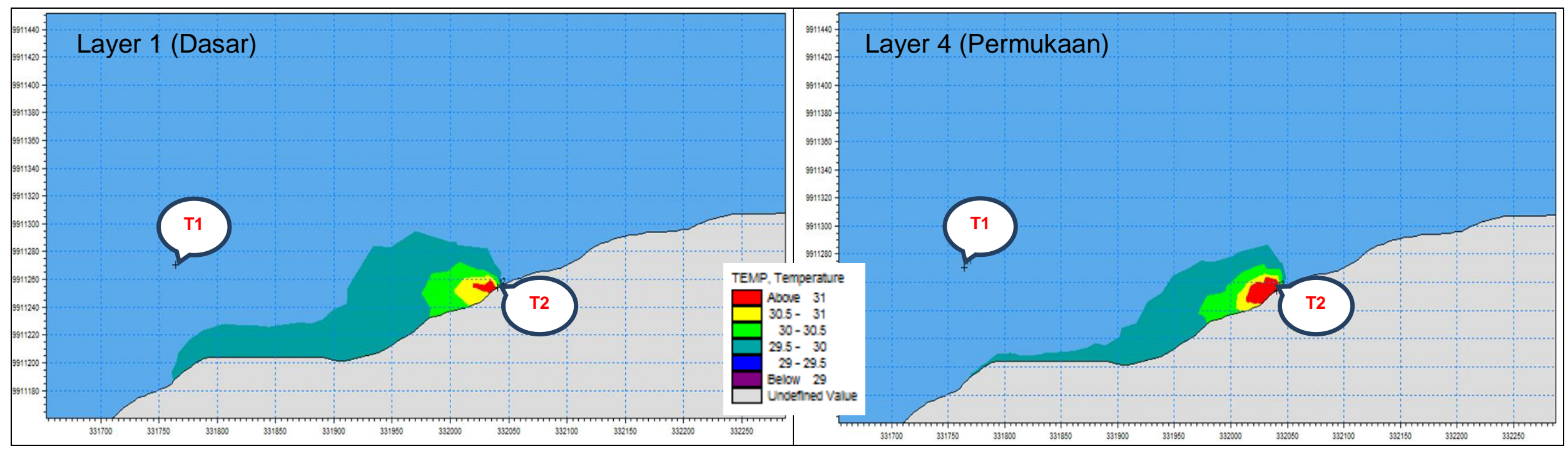

Gambar 9. Pola dispersi panas skenario musim angin barat, kondisi menuju pasang 
Pada kondisi air surut terlihat bahwa sebaran panas di sekitar outfall untuk tiap-tiap lapisan kedalaman (layer) menunjukkan pola yang hampir sama, atau dengan kata lain dapat dikatakan homogen secara vertikal. Hal ini terjadi karena pada kondisi surut kolom air menjadi lebih dangkal sehingga proses percampuran (mixing) berlangsung lebih cepat dan seragam. Profil temperatur vertikal di lokasi outfall pada saat air surut terlihat pada gambar 10 berikut.

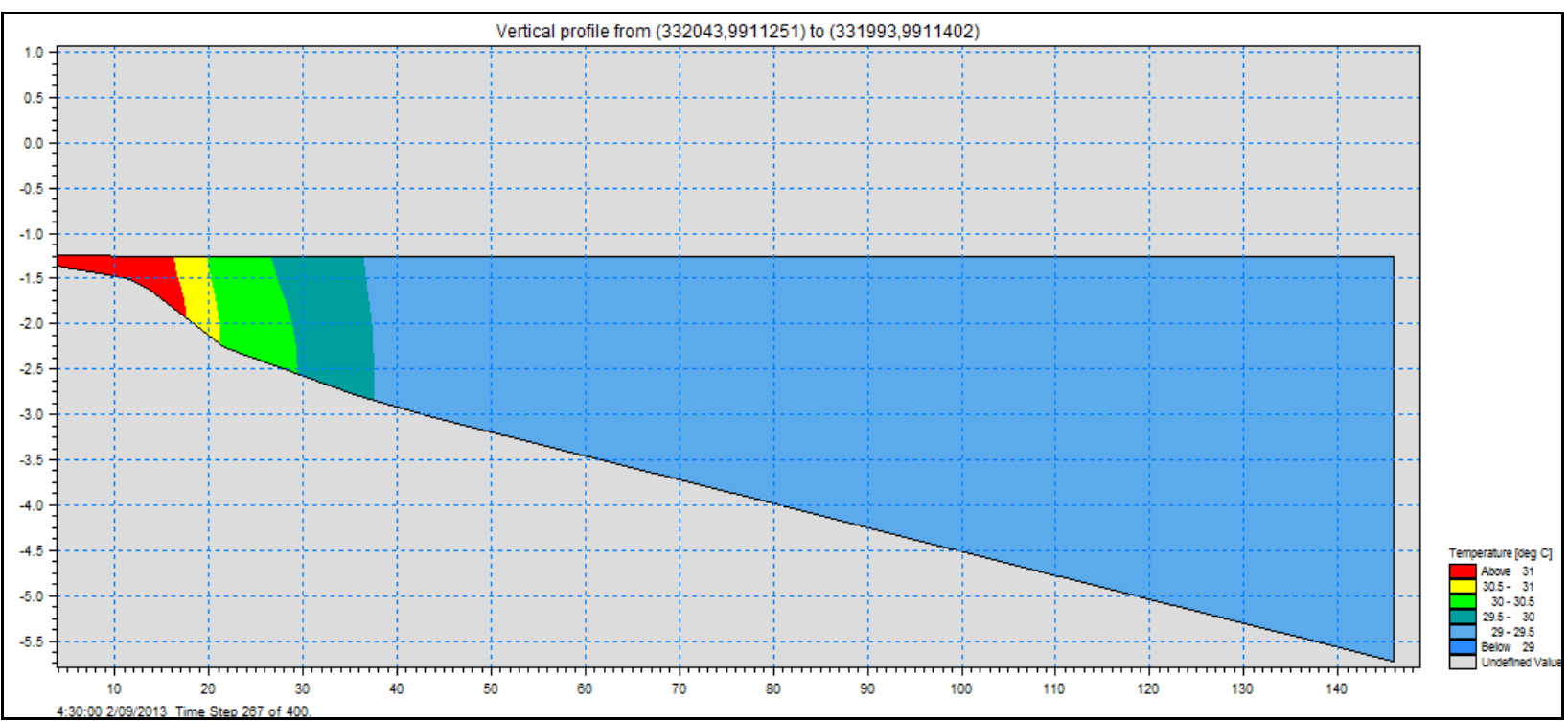

Gambar 10. Profil vertikal temperatur air bahang di lokasi outfall, saat surut

Pada kondisi pasang tertinggi terlihat bahwa sebaran panas di sekitar outfall untuk tiap-tiap lapisan kedalaman (layer) menunjukkan pola yang berbeda, yaitu pada lapisan permukaan lebih luas sebarannya dibandingkan pada lapisan dekat dasar. Hal ini terjadi karena pada kondisi pasang kolom air menjadi lebih dalam sehingga memungkinkan terjadinya stratifikasi, dimana air dengan temperatur lebih tinggi (densitasnya lebih ringan) akan berada di lapisan permukaan. Profil temperatur vertikal di lokasi outfall pada saat air pasang terlihat pada gambar 11 .

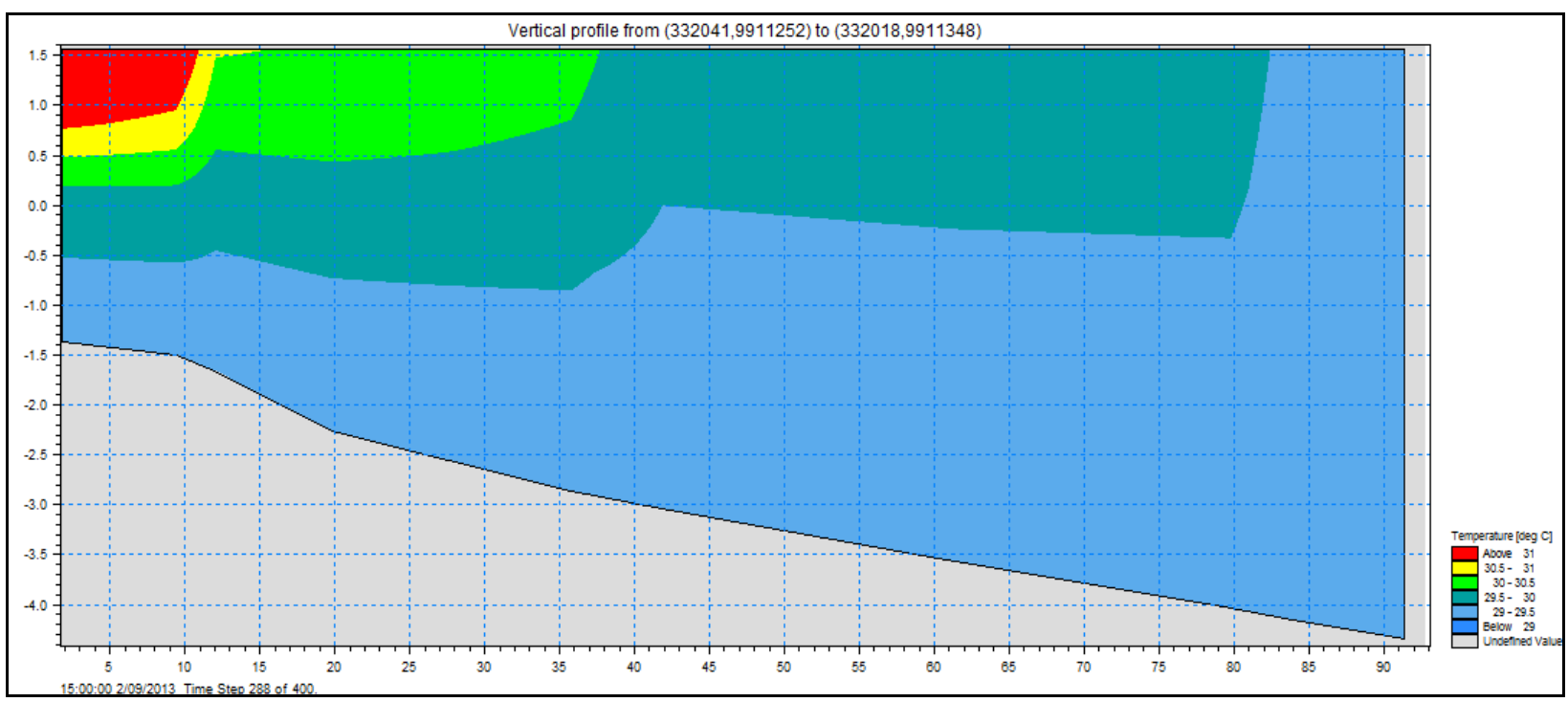

Gambar 11. Profil Vertikal Temperatur Air Bahang di Lokasi Outfall, Saat Pasang 


\section{KESIMPULAN}

Berdasarkan hasil pemodelan hidrodinamika dan dispersi termal yang telah dilakukan dengan berbagai skenario model, diperoleh kesimpulan sebagai berikut:

a. Penempatan lokasi outfall pada Alternatif 1 maupun Alternatif 2 tidak memberikan perbedaan yang signifikan terhadap temperatur di lokasi intake. Hasil simulasi menunjukkan bahwa Alternatif 1 memberikan hasil perubahan temperatur intake yg lebih kecil dibandingkan Alternatif 2. Bila posisi outfall sesuai Alternatif 2 akan diterapkan, maka perlu dilakukan pengerukan batimetri di depan lokasi outfall, sehingga menjadi lebih dalam.

b. Sebaran air bahang dengan perbedaan temperatur terhadap suhu air ambien $(\Delta \mathrm{T})$ $0.5^{\circ} \mathrm{C}-1{ }^{\circ} \mathrm{C}$ mencapai jarak terjauh $300 \mathrm{~m}$ dari outfall ke arah hilir/timur-laut saat menuju surut, dan $300 \mathrm{~m}$ ke arah hulu/baratdaya saat air menuju pasang. Sebaran air bahan dengan $\Delta T>2{ }^{\circ} \mathrm{C}$ hanya mencapai jarak $30 \mathrm{~m}$ pada skenario musim timur, sedangkan pada musim barat mencapai 45 $\mathrm{m}$ ke arah timur outfall.

c. Pada kondisi air surut terlihat bahwa sebaran panas di sekitar outfall untuk tiap-tiap lapisan kedalaman (layer) menunjukkan pola yang hampir sama, atau dengan kata lain dapat dikatakan homogen secara vertikal.

d. Pada kondisi pasang tertinggi terlihat bahwa sebaran panas di sekitar outfall untuk tiaptiap lapisan kedalaman (layer) menunjukkan pola yang berbeda, yaitu pada lapisan permukaan lebih luas sebarannya dibandingkan pada lapisan dekat dasar.

\section{PERSANTUNAN}

Terima kasih penulis ucapkan kepada PT. ZUG Industry Indonesia, manajemen Balai Teknologi Infrastruktur Pelabuhan dan Dinamika Pantai dan seluruh pelaksana kegiatan "Studi Dispersi Termal PLTU Kuala Tungkal $2 \times 7$ MW, Jambi”.

\section{DAFTAR PUSTAKA}

1. BPS Kabupaten Tanjung Jabung Barat. (2013). Tanjung Jabung Barat Dalam Angka 2013, http://tanjabbarkab.bps.go.id/
2. BAPPEDA Tanjung Jabung Barat. (2011). RPJM Kab. Tanjung Jabung Barat 2011 2016.

3. Nurjaya, I.W. and Surbakti, H. (2010). Model Dispersi Bahang Hasil Buangan Air Proses Pendinginan PLTGU Cilegon CCPP ke Perairan Pantai Margasari di Sisi Barat Teluk Banten, E-Jurnal IImu dan Teknologi Kelautan Tropis, DITK-IPB. 2(1): 31-49

4. Fudlailah, P., Mukhtasor, Zikra, M. (2015). Pemodelan Penyebaran Limbah Panas di Wilayah Pesisir (Studi Kasus Outfall PLTU Paiton), from http://digilib.its.ac.id/public/ITSpaper-31211-4309100011-paper.pdf (viewed 10 January, 2017)

5. Yustiani, Y.M., Wahyuni, S., Wahyuni, N.A. (2015). Pemodelan Matematis Sebaran Buangan Panas Cair dari Proses Pendinginan Pembangkit Listrik Tenaga Uap Banten Labuan, Jurnal Infoma Tek, FTUNPAS. 17(1): 15-24.

6. Asfaq, SM. (2015). Thermal Dispersion Model for Cooling Water of Thermal Power Plant System. International Journal of Current Engineering and Technology V.5 No.4. INPRESSCO: 2472-2477

7. Huboyo, H.S., dan Zaman, B. (2007). Analisis Sebaran Temperatur dan Salinitas Air Limbah PLTU-PLTGU Berdasarkan Sistem Pemetaan Spasial (Studi Kasus; PLTU-PLTGU Tambak Lorok-Semarang), Jurnal Presipitasi, UNDIP. 3(2)

8. Shah V, Dekhatwala A, Banerjee J. (2017). Journal Sadhana V 42, No. 4. Pp 557-574

9. Anonim. (2001). Peraturan Pemerintah No. 82 Tahun 2001 tentang Pengelolaan Kualitas Air dan Pengendalian Pencemaran Air.

10. Anonim. (2004). Peraturan Menteri Lingkungan Hidup No.51 tahun 2004 mengenai Baku Mutu air laut.

11. Cahyana, C. (2011). Model Sebaran Panas Air Kanal Pendingin Instalasi Pembangkit Listrik ke Badan Air Laut, Prosiding Seminar Nasional Teknologi Pengelolaan Limbah IX, Pusat Teknologi Limbah Radioaktif-BATAN dan FT-Universitas Sultan Ageng Tirtayasa, 5 Oktober 2011, Banten, h. 293-302

12. Anonim. (2012). MIKE 3 Flow Model FM Hydrodynamic Module - User Guide, DHI, (2011).

13. Sana A. (2009). Hydrodynamic and Thermal Dispersion Modelling of the Effluent in a Coastal Channel. Presentation Material at Sultan Qaboos University-Oman. 
14. Abbaspour $M$, Javid $A H$, Moghini $P$, Kayhan K. (2006). Modeling of Thermal Pollution in The Northern Coastal Area of The Persian Gulf and It's Economical and Environmental Assessment. Water Pollution VIII:Modeling, Monitoring and Management. WIT Transctions on Ecology and the Environment Vol 95. pp 445-453.

15. Gupta A, Vijay R, Kushwaha VK and Wate SR. (2014). Identification of Inlet and Outlet for Cool Seawater Duscharges from an LNG
Facility. International Journal of Environmental Research Vol 8 No. 4. pp 953960.

16. BTIPDP. (2013). Laporan Survei Hidrooseanografi S. Mentaya, Sampit, Kab. Kotawaringin Timur. Laporan Internal.

17. Anonim. (2012). Tender Document: PLTU Kuala Tungkal $(2 \times 7 \mathrm{Mw})$, Book II, PART IV Technical Requirement, Section 4.1. Project Description. 